\title{
Some Rare and Insufficiently Studied Snailfish (Liparidae, Scorpaeniformes, Pisces) in the Pacific Waters off the Northern Kuril Islands and Southeastern Kamchatka, Russia
}

\author{
A. M. Orlov' ${ }^{1}$ and A. M. Tokranov ${ }^{2}$ \\ ${ }^{1}$ Laboratory of Atlantic Basin, Department of International Fisheries Cooperation, Russian Federal Research Institute of \\ Fisheries and Oceanography (VNIRO), 17 V. Krasnoselskaya, Moscow 107140, Russia \\ ${ }^{2}$ Kamchatka Branch of Pacific Institute of Geography, Far East Branch of Russian Academy of Sciences, 6 Partizanskaya, \\ Petropavlovsk-Kamchatsky 683000, Russia \\ Correspondence should be addressed to A. M. Orlov, orlov@vniro.ru
}

Received 19 January 2011; Accepted 13 March 2011

Academic Editors: D. Park and M. Mooring

Copyright (๑) 2011 A. M. Orlov and A. M. Tokranov. This is an open access article distributed under the Creative Commons Attribution License, which permits unrestricted use, distribution, and reproduction in any medium, provided the original work is properly cited.

\begin{abstract}
Spatial and vertical distributions, size-weight compositions, age, and diets of 10 rare or poorly known snailfish (Liparidae) from the Pacific off the southeastern Kamchatka and the northern Kuril Islands are described. The species include blacktip snailfish Careproctus zachirus, Alaska snailfish C. colletti, blacktail snailfish C. melanurus, proboscis snailfish C. simus, falcate snailfish C. cypselurus, big-disc snailfish Squaloliparis dentatus, longtip snailfish Elassodiscus obscurus, slender snailfish Paraliparis grandis, gloved snailfish Palmoliparis beckeri, and stout snailfish Allocareproctus jordani. These species inhabit a wide range of depths. Careproctus melanurus, C. cypselurus, E. obscurus, P. grandis, and C. colletti are the deepest; C. simus and S. dentatus occur mostly between 300 and $600 \mathrm{~m}$; the three other species seldom occur at depths of 150-200 m. The life span of these species is 10-13 years, and specimens of age classes $2-5$ constitute the bulk of catches. All except $A$. jordani are benthophages that eat small crustaceans, shrimps, hermit crabs, and amphipods. A. jordani consumes crustaceans and also polychaete worms, sea snails, octopi, brittle stars, juvenile fish, and fishery offal.
\end{abstract}

\section{Introduction}

The family Liparidae is one of the most diverse and abundant fish families in polar and deep-sea habitats [1] and includes species that occur from littoral to ultra-abyssal depths [2]. There are about 50 species in this family in Pacific waters off Kamchatka and the northern Kuril Islands, constituting almost $10 \%$ of the total number of fish species inhabiting this area [3-7]. These fish are relatively abundant in number and biomass on the lower part of the continental shelf as well as on the upper continental slope $(100-800 \mathrm{~m})$ in most areas of the Far Eastern Seas [3, 4, 8-11]. They are food for and potential food competitors of commercial fish species in groundfish communities. However, until now, snailfish have been poorly studied even in terms of their taxonomy [1]. Published information regarding occurrence, spatialbathymetric distribution, and biology of most snailfish in the North Pacific as a whole and in waters adjacent to the Kuril Islands and Kamchatka in particular is extremely limited. The majority of papers containing information on the North Pacific liparids [12-20] are dealing mostly with their taxonomy, geographic and bathymetric ranges, new records, and eventually contain limited information on general biology.

In 1993-2002, in a program to study poorly known and underexploited fish of the continental slope of the Far Eastern Seas in the Pacific waters off the northern Kuril Islands and southeastern Kamchatka (the area from $47^{\circ} 50^{\prime}$ to $52^{\circ} 00^{\prime} \mathrm{N}$, depths of $83-850 \mathrm{~m}$ ), the Russian Federal (VNIRO), Kamchatka (KamchatNIRO), and Sakhalin (SakhNIRO) Research Institutes of Fisheries and Oceanography jointly carried out more than 60 fishery research cruises onboard Japanese trawlers specially equipped for bottom trawling in areas of the continental slope with rugged topography, in the course of which new data on snailfish distribution and biology were collected. 
TABLE 1: Number of specimens examined in this study.

\begin{tabular}{lcccc}
\hline Species & Measured & $\begin{array}{c}\text { Length- } \\
\text { weight }\end{array}$ & Aged & $\begin{array}{c}\text { Stomach } \\
\text { content }\end{array}$ \\
\hline Allocareproctus jordani & 127 & 83 & 10 & 10 \\
Careproctus zachirus & 159 & 86 & 32 & 32 \\
C. colletti & 67 & 16 & 5 & 5 \\
C. cypselurus & 100 & 97 & 97 & 100 \\
C. melanurus & 192 & 34 & - & 5 \\
C. simus & 16 & 24 & - & - \\
Elassodiscus obscurus & 153 & 72 & 72 & 100 \\
Palmoliparis beckeri & 27 & 19 & 8 & 10 \\
Paraliparis grandis & 105 & 55 & 55 & 55 \\
Squaloliparis dentatus & 30 & 51 & - & - \\
\hline
\end{tabular}

We provide information in this paper regarding occurrence, spatial-bathymetrical distribution, size-age composition and diets of 10 rare or insufficiently studied snailfishes in Pacific waters off the northern Kuril Islands and southeastern Kamchatka, including Alaska snailfish Careproctus colletti Gilbert, 1896, blacktip snailfish C. zachirus Kido, 1985, blacktail snailfish C. melanurus, Gilbert, 1892, proboscis snailfish C. simus, Gilbert, 1896, falcate snailfish C. cypselurus (Jordan and Gilbert, 1898), big-disc snailfish Squaloliparis dentatus (Kido, 1988), longtip snailfish Elassodiscus obscurus Pitruk et Fedorov, 1993 (new common English name proposed), slender snailfish Paraliparis grandis Schmidt, 1950, gloved snailfish Palmoliparis beckeri Balushkin, 1996 and stout [7] or cherry [21] snailfish Allocareproctus jordani (Burke, 1930).

\section{Material and Methods}

Data for this paper are based on analysis of catches of approximately 11,000 bottom-trawl hauls at depths of 83$850 \mathrm{~m}$ (near-bottom temperatures were measured for most hauls) carried out in April-December 1993-2002 aboard the Japanese trawlers "Tomi-Maru-53," "Tomi-Maru-82," and "Tora-Maru-58" under the VNIRO-SakhNIROKamchatNIRO joint program (hereafter referred to as the 1993-2002 survey). Hauls were made 24 hours a day using bottom trawls with vertical opening of 5-7 $\mathrm{m}$ and horizontal opening of $25 \mathrm{~m}$ (the parameters of the trawl openings were checked by equipment) at an average speed of 3.6 knots. Because trawl duration varied from 0.5 to 10 hours, all the catches were later normalized to a standard one-hour haul. Distributions of individual species by depth and bottom temperature were analyzed by frequency of occurrence (in percent), calculated based on average catch per hour.

Snailfish were identified to species using keys and descriptions by Gilbert and Burke [22], Burke [23], Hart [24], Stein [25], Kido [26-28], Masuda et al. [29] Pitruk and Fedorov [30-32], Amaoka et al. [33] and Balushkin [34].

To study size-age composition, length measurements and biological analyses of the 10 snailfish species studied were used (datasets for each of the species are given in Table 1).

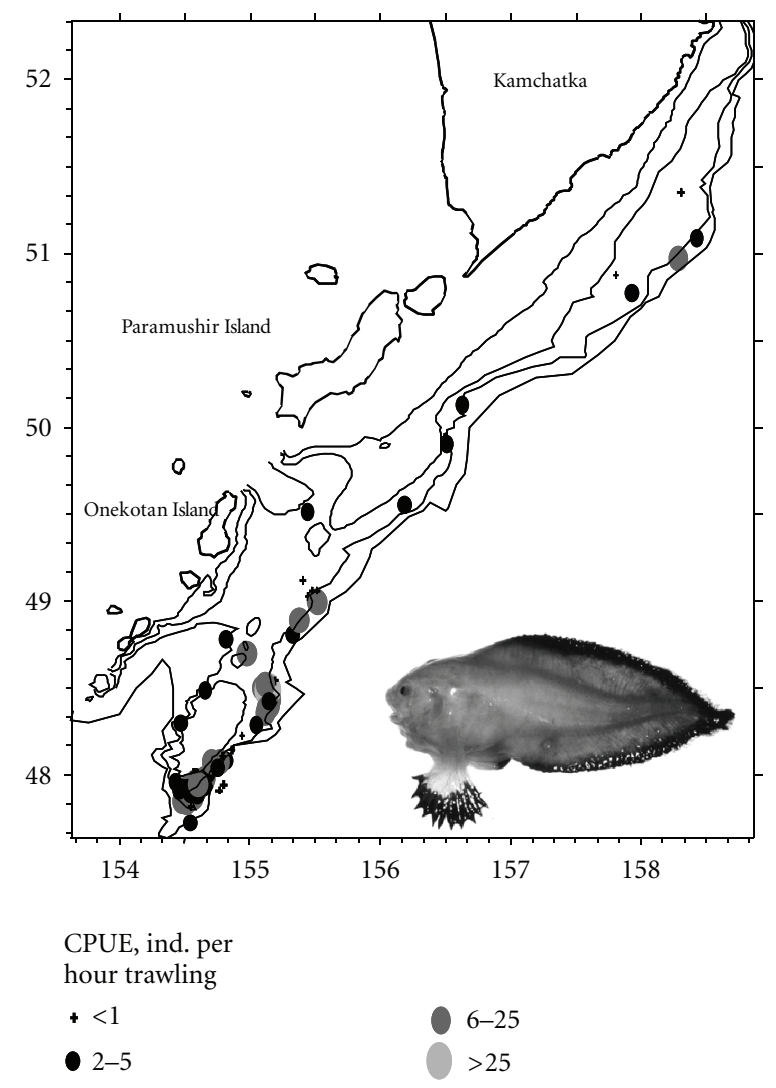

FIGURE 1: Distribution and relative abundance categorized by CPUE (specimens per hour trawling) of Careproctus zachirus in the Pacific waters off the northern Kuril Islands and southeastern Kamchatka, April-December 1993-2002 (numbers are maximum catches; thin lines are isobaths at 100, 200, 500, and $1000 \mathrm{~m}$ ).

Age was determined by otoliths using the "break and burn" technique. We assumed annuli were annual. Diet was determined from the results of field analyses made in August-December 1996-2002.

\section{Results and Discussion}

\subsection{Occurrence and Bathymetry}

Blacktip Snailfish Careproctus zachirus. First described in 1985 from the Bering Sea [27]. It is a high-boreal Asiatic species, from the northern part of the Sea of Okhotsk, off the northern Kuril Islands, eastern Kamchatka, and in the western part of the Bering Sea off the western Aleutian Islands $[5-7,11,35,36]$. The 1993-2002 survey observed it between $47^{\circ} 50^{\prime}$ to $51^{\circ} 30^{\prime} \mathrm{N}$, with maximum catches ( $>25$ specimens/h) from the southern part of the surveyed area, preliminarily from the continental slope of the northern Kuril Islands (Figure 1).

C. zachirus is a mesobenthic species inhabiting depths of 214-850 $\mathrm{m}[6,7]$. This species was caught at depths of $150-800 \mathrm{~m}$ with near-bottom temperatures of $3.0-3.6^{\circ} \mathrm{C}$ and concentrated mainly in $400-500 \mathrm{~m}$ where more than $56 \%$ of the specimens were observed (Table 2). 
TABLE 2: Bathymetric distribution (percentage of relative abundance within certain depth range) of different snailfish species off the northern Kuril Islands and southeastern Kamchatka.

\begin{tabular}{|c|c|c|c|c|c|c|c|}
\hline \multirow{2}{*}{ Species } & \multicolumn{7}{|c|}{ Depth, m } \\
\hline & $101-200$ & $201-300$ & $301-400$ & $401-500$ & $501-600$ & $601-700$ & $701-800$ \\
\hline C. zachirus & 0.3 & 7.2 & 17.8 & 56.2 & 16.0 & 2.1 & 0.4 \\
\hline C. colletti & 0.0 & 0.0 & 1.1 & 29.5 & 53.2 & 16.2 & 0.0 \\
\hline C. melanurus & 0.0 & 0.2 & 4.3 & 12.0 & 41.4 & 25.4 & 16.7 \\
\hline C. simus & 0.0 & 8.7 & 34.0 & 49.4 & 7.9 & 0.0 & 0.0 \\
\hline C. cypselurus & 0.0 & 0.0 & 5.7 & 33.0 & 38.6 & 16.4 & 6.3 \\
\hline E. obscurus & 0.0 & 0.1 & 1.6 & 17.7 & 49.4 & 13.4 & 17.8 \\
\hline P. grandis & 0.0 & 0.1 & 7.9 & 8.2 & 44.0 & 37.6 & 2.2 \\
\hline S. dentatus & 0.0 & 39.1 & 60.7 & 0.1 & 0.1 & 0.0 & 0.0 \\
\hline P. beckeri & 0.0 & 7.7 & 26.9 & 38.5 & 9.6 & 10.3 & 7.0 \\
\hline A. jordani & 3.5 & 5.3 & 27.1 & 60.0 & 1.2 & 2.6 & 0.3 \\
\hline
\end{tabular}

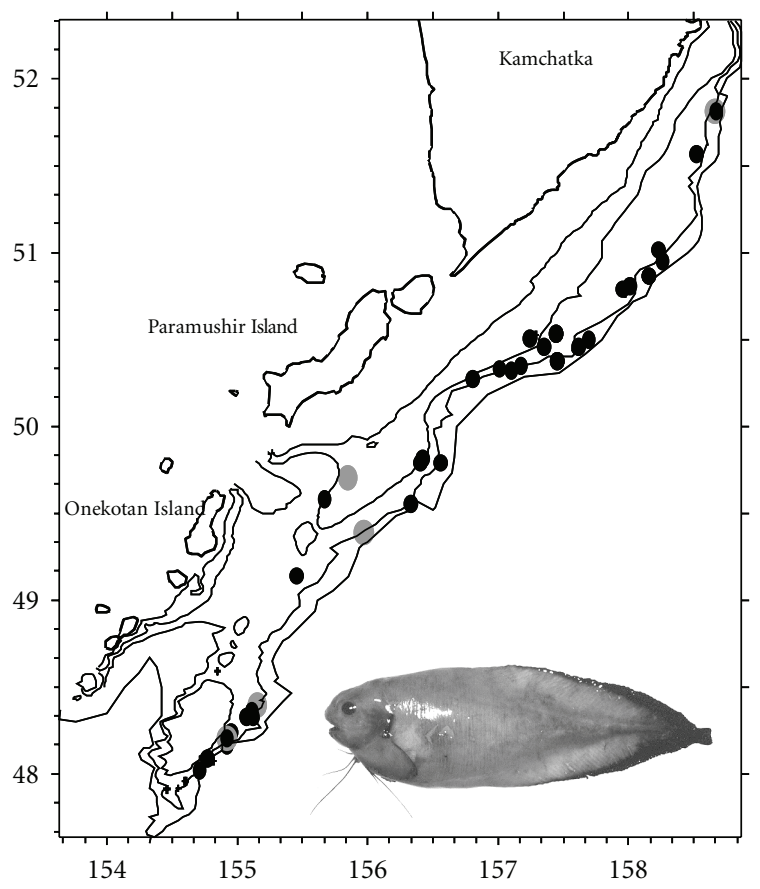

CPUE, ind. per hour trawling

$+<1$

- $1-5$

$>5$

FIGURE 2: Distribution and relative abundance categorized by CPUE (specimens per hour trawling) of Careproctus colletti in the Pacific waters off the northern Kuril Islands and southeastern Kamchatka, April-December 1993-2002.

Alaska Snailfish Careproctus colletti. This is a boreal Asiatic species widely distributed in the northern part of the Sea of Japan, Sea of Okhotsk, and Bering Sea [7, 37], and in Pacific waters off Hokkaido [33], northern Kuril Islands, southeastern Kamchatka [5, 6, 11, 35], and the Gulf of
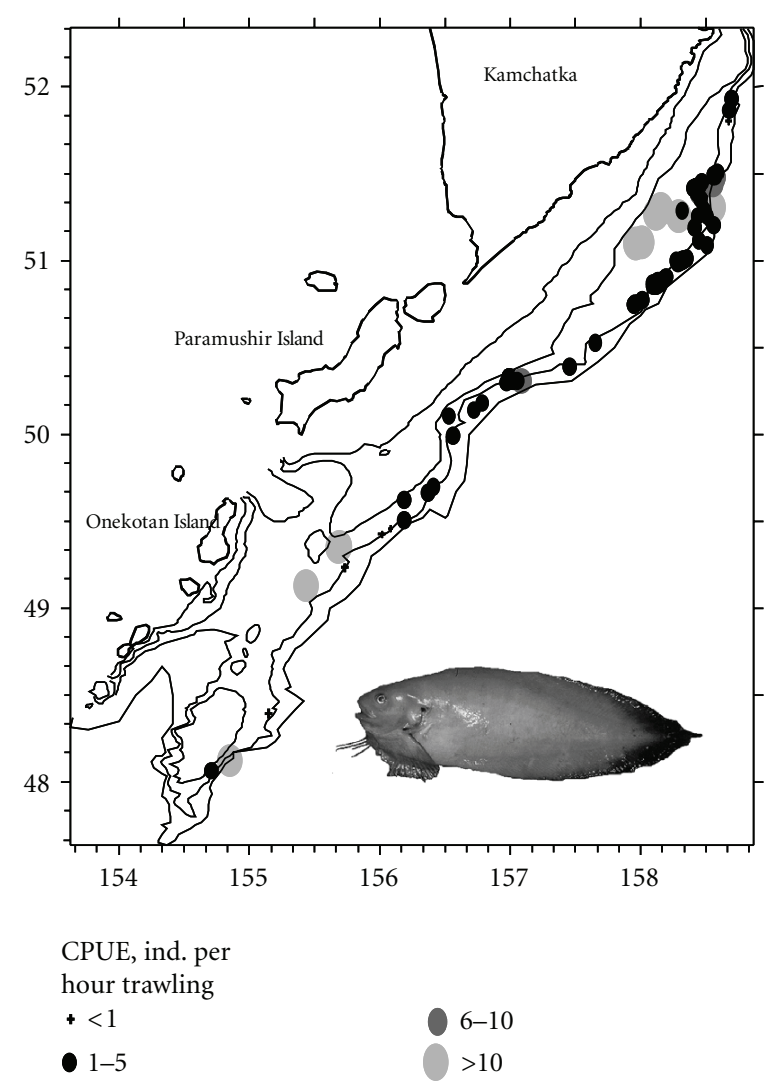

FIGURE 3: Distribution and relative abundance categorized by CPUE (specimens per hour trawling) of Careproctus melanurus in the Pacific waters off the northern Kuril Islands and southeastern Kamchatka, April-December 1993-2002.

Alaska [36]. We found C. colletti throughout the survey area with maximum catches ( $>5$ specimens $/ \mathrm{h}$ ) recorded in its northernmost and southernmost parts (Figure 2).

C. colletti is a part of the mesobenthic community and is known from depths of $64-1,350 \mathrm{~m}[6,7]$. We found it at 


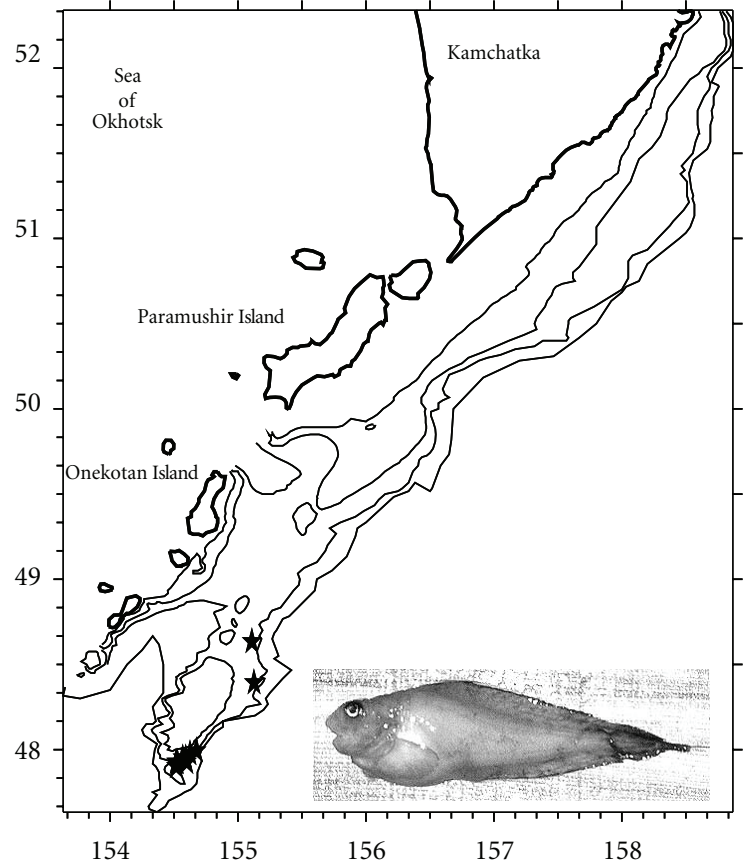

FIgURE 4: Capture sites $(*)$ of Careproctus simus off the northern Kuril Islands, August-December 1998-2002.

$360-700 \mathrm{~m}$ at near-bottom temperatures of $3.0-3.6^{\circ} \mathrm{C}$. The majority of specimens (about 83\%) were caught between 400 and $600 \mathrm{~m}$ (Table 2).

Blacktail Snailfish Careproctus melanurus. This is a boreal Pacific species widely distributed in the north Pacific from the Bering Sea to the Sea of Japan, and along the Pacific coast of Japan in the west to California in the east $[7,36]$. Until recently, C. melanurus was known primarily from the American coast from British Columbia to California [23, 24, 38-41]. In Asian waters, it is known from the Bering Sea $[42,43]$, the Pacific off southeastern Kamchatka, the northern Kuril Islands [5, 6, 43], and off Japan [44]. Previous information regarding its distribution off the Pacific coast of Kamchatka and the northern Kuril Islands was limited $[35,43]$. We found it in the Pacific coast from $48^{\circ} 00^{\prime}$ to $52^{\circ} 00^{\prime} \mathrm{N}$ (Figure 3). Most catches were recorded in the central and northern parts of the survey area, although one catch of maximum size ( $>10$ specimens/h) was from the south on the eastern slope of underwater plateau.

Unlike C. zachirus and C. colletti, C. melanurus is a bathybenthic species known from depths of 89-2,286 m, but primarily between 500 and 1,600 $\mathrm{m}[6,7,45]$. Our data showed this species occurred at depths from 285 to $800 \mathrm{~m}$, with near-bottom temperatures of $3.0-3.6^{\circ} \mathrm{C}$, but most specimens (over 66\%) were caught in 500-700 m (Table 2).

Proboscis Snailfish Careproctus simus. This species is boreal Asiatic, widely distributed in the northern part of the Pacific Ocean between $45^{\circ} \mathrm{N}$ and $60^{\circ} \mathrm{N}$ including the Sea of Japan, the Sea of Okhotsk off Hokkaido and southeastern Sakhalin,

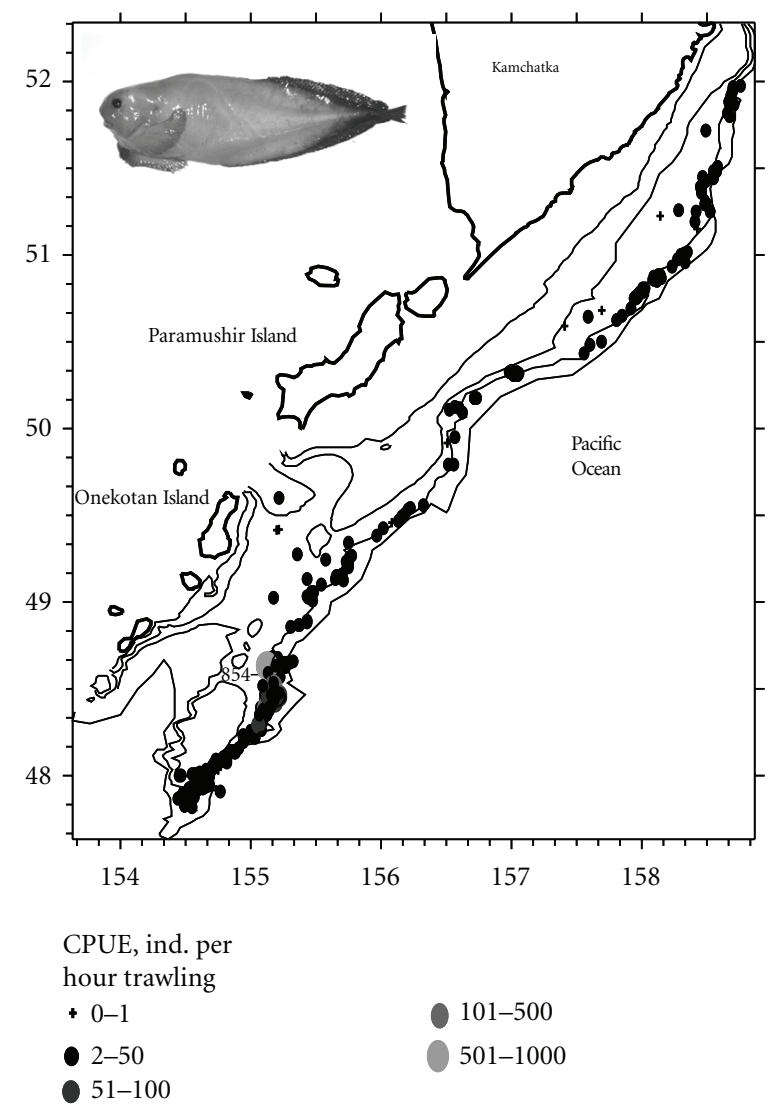

FIGURE 5: Distribution and relative abundance categorized by CPUE (specimens per hour trawling) of Careproctus cypselurus in the Pacific waters off northern Kuril Islands and southeastern Kamchatka, April-December 1993-2002.

the Bering Sea, the Aleutian Islands, and the northern Kuril Islands [7, 27, 36, 46]. However, data on its spatialbathymetric distribution is limited by capture depths. In our studies, only 1-2 specimens/h were registered in catches in August-December 1998-2002 in the southernmost part of the surveyed area, along the eastern slope of the northern part of the outer Kuril chain (Figure 4).

Data from Chernova et al. [36] suggest that $C$. simus is a rare mesobenthic species known from depths of 380-800 m. Our data from catches in the Pacific off the northern Kuril Islands in August-December showed it occurs at depths from 370 to $630 \mathrm{~m}$ at near-bottom temperatures of $3.4-3.6^{\circ} \mathrm{C}$, with most (>83\%) caught at 400-600 m (Table 2).

Falcate Snailfish Careproctus cypselurus. This is a boreal Pacific species pervasive in the northern Pacific Ocean from the Bering Sea to the Sea of Japan and the Pacific coast of Japan in the west to British Columbia and the states of Washington and Oregon in the east [36, 37], and off the northern Kuril Islands and southeastern Kamchatka [5, 6, 11]. Our studies confirm its occurrence throughout the area (Figure 5). However, it was observed most frequently to the southeast $\left(47^{\circ} 50^{\prime} \mathrm{N}\right.$ to $\left.48^{\circ} 50^{\prime} \mathrm{N}\right)$, where maximum number of C. cypselurus (854 specimens) was caught, although usually catches were fewer than 30-50 specimens/h. 


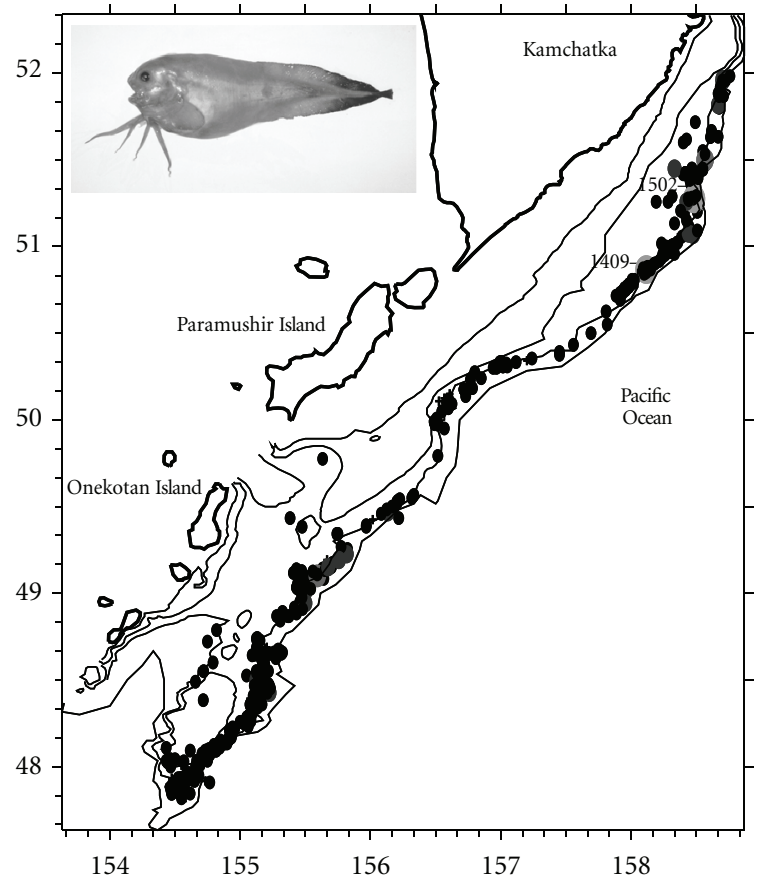

$$
\begin{aligned}
& \text { CPUE, ind. per } \\
& \text { hour trawling } \\
& +0-1 \\
& \text { - } 2-100
\end{aligned}
$$

FIGURE 6: Distribution and relative abundance categorized by CPUE (specimens per hour trawling) of Elassodiscus obscurus in the Pacific waters off the northern Kuril Islands and southeastern Kamchatka, April-December 1993-2002.

C. cypselurus is a bathybenthic species known from depths of 35-1,993 m, but inhabiting mainly depths of 450 $1,500 \mathrm{~m}[6,7,36]$. We found this snailfish at depths of 330 $800 \mathrm{~m}$, but most were at $400-600 \mathrm{~m}$ (Table 2), where $72 \%$ were caught.

Longtip Snailfish Elassodiscus obscurus. This species was described from the southern Sea of Okhotsk [30] and is as a wide-boreal Asiatic species distributed in the Sea of Okhotsk off southwestern Kamchatka, in the Pacific off Kamchatka and the Kuril Islands [6, 7, 36], and in the eastern [47] and western Bering Sea $\left(60^{\circ} 48.9^{\prime} \mathrm{N}, 179^{\circ} 03.7^{\prime} \mathrm{E}, 660\right.$ $665 \mathrm{~m}, 1$ specimen; $61^{\circ} 32.6^{\prime} \mathrm{N}, 177^{\circ} 52.1^{\prime} \mathrm{E}, 460-450 \mathrm{~m}$, 9 spec.; $61^{\circ} 33.5^{\prime} \mathrm{N}, 178^{\circ} 04.8^{\prime} \mathrm{E}, 320 \mathrm{~m}, 1$ spec.; $60^{\circ} 21.3^{\prime} \mathrm{N}$, $171^{\circ} 46.0^{\prime} \mathrm{E}, 670-675 \mathrm{~m}, 1 \mathrm{spec}$. Our data). We found that E. obscurus is a common and rather abundant species on the Pacific side of the northern Kuril Islands and the southeastern coast of Kamchatka [5, 11].

E. obscurus occurred on the continental slope of the entire Pacific coast survey area (Figure 6). However, maximum catches (up to $1,400-1,500$ specimens/h) came from southeastern Kamchatka (from $50^{\circ} 50^{\prime} \mathrm{N}$ to $51^{\circ} 30^{\prime} \mathrm{N}$ ).

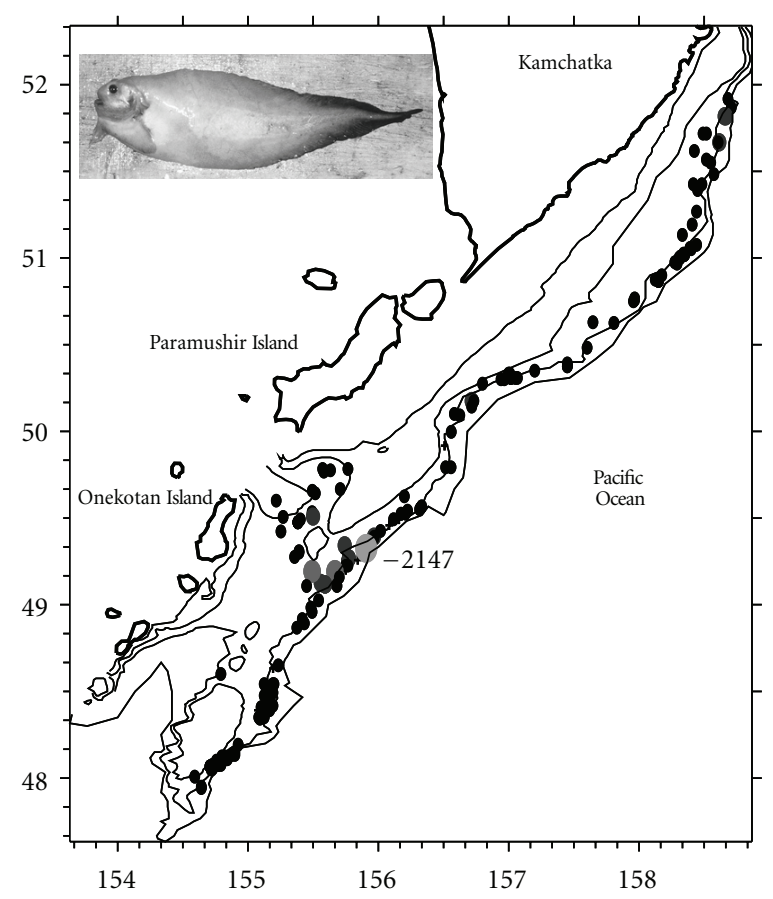

CPUE, ind. per

hour trawling

$$
\begin{aligned}
& \text { + 0-1 } \\
& \text { - 2-100 } \\
& \text { 101-500 }
\end{aligned}
$$

FIGURE 7: Distribution and relative abundance categorized by CPUE (specimens per hour trawling) of Paraliparis grandis in the Pacific waters off the northern Kuril Islands and southeastern Kamchatka, April-December 1993-2002.

E. obscurus is a mesobenthic species inhabiting depths of $161-1,773 \mathrm{~m}$, but predominantly occurring in $550-1,200 \mathrm{~m}$ $[6,7]$. This snailfish occurred at depths of $260-800 \mathrm{~m}$ (Table 2) with near-bottom temperatures of $0.4-3.7^{\circ} \mathrm{C}$, with about $50 \%$ caught in $500-600 \mathrm{~m}$.

Slender Snailfish Paraliparis grandis. First described in 1950 based on a single specimen caught in the northern Sea of Okhotsk at a depth of $592 \mathrm{~m} \mathrm{[48].} \mathrm{It} \mathrm{is} \mathrm{known} \mathrm{to} \mathrm{be} \mathrm{widely}$ distributed in the Sea of Okhotsk and the western Bering Sea $[7,26,28,49,50]$. In Pacific waters off the northern Kuril Islands and southeastern Kamchatka, P. grandis is common and even rather abundant $[5,6,11]$.

Similar to E. obscurus, P. grandis is pervasive throughout the area (Figure 7). However, its maximum catches ( $>1,000$ specimens/h) were abeam the Fourth Kuril Strait, southeast of Paramushir Island.

It is a mesobenthic species known from 105-1,995 m, but inhabiting mainly depths of 450-900 $\mathrm{m}[6,7]$. We caught it at depths of 260-800 m with near-bottom temperatures of 2.6$3.7^{\circ} \mathrm{C}$, although approximately $82 \%$ were caught between 500 and $700 \mathrm{~m}$ (Table 2). 


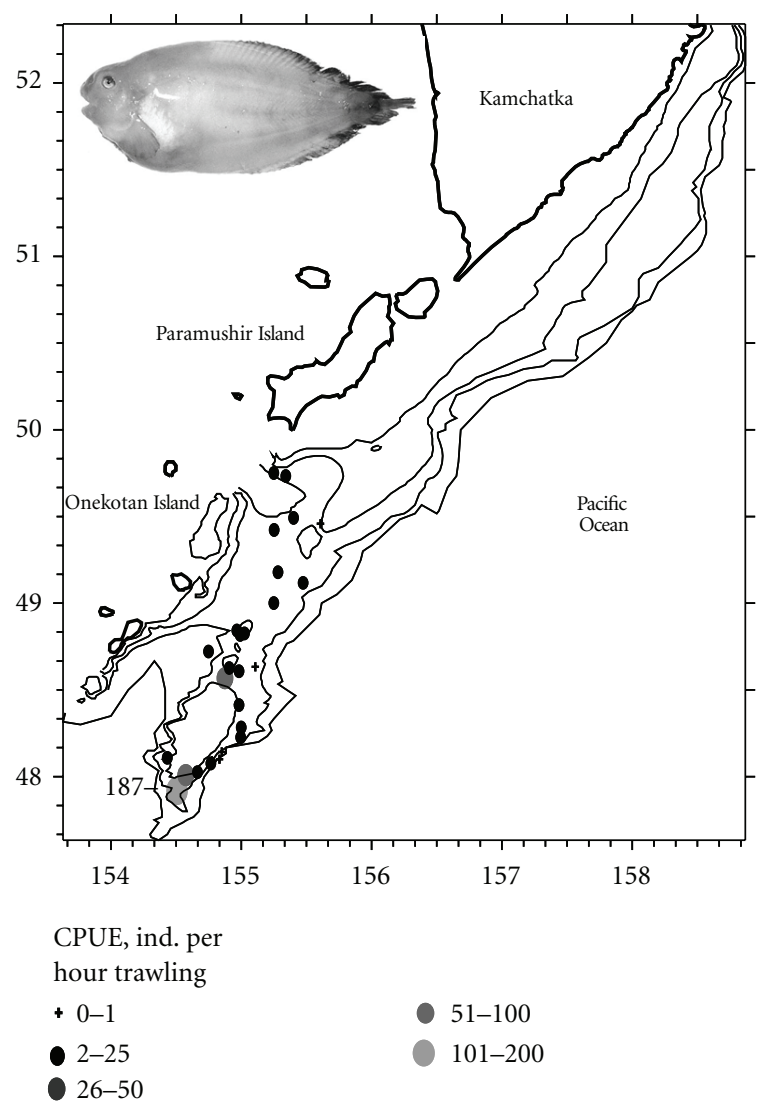

Figure 8: Distribution and relative abundance categorized by CPUE (specimens per hour trawling) of Squaloliparis dentatus in the Pacific waters off the northern Kuril Islands, July-November, 1995-2002.

Big-Disc Snailfish Squaloliparis dentatus. First described from the Sea of Okhotsk waters off the Hokkaido as Careproctus dentatus, [28], it is now placed in the genus Squaloliparis, [31]. It is fairly common and widely distributed in the bathyal of the Sea of Okhotsk as well as in the Pacific off the northern Kuril Islands and southeastern Kamchatka $[6,7,11,31,36]$. We captured it only to the south from $47^{\circ} 50^{\prime} \mathrm{N}$ to the Fourth Kuril Strait (Figure 8), with the maximum catches (the largest with 187 specimens/h) registered on the slopes of the underwater elevation.

$S$. dentatus is a mesobenthic species known from depths of $120-900 \mathrm{~m}$ [6, 7, 31]. In the Sea of Okhotsk, most specimens were caught in 400-500 $\mathrm{m}$ [31]. Catches from Pacific waters off the Kuril Islands were at depths from 260 to $570 \mathrm{~m}$, with near-bottom temperatures of $1.6-3.4^{\circ} \mathrm{C}$. About $61 \%$ were from $300-400 \mathrm{~m}$ (Table 2).

Gloved Snailfish Palmoliparis beckeri. Described from the Pacific off the northern Kuril Islands [34] and subsequently characterized as a rare, widely distributed boreal Asiatic species from off the Kuril Islands and southeastern Kamchatka [6, 7, 36]. All known specimens (about 30) were caught in Pacific waters off the northern Kuril Islands in the area to the south of the Fourth Kuril Strait [11, 34, $35,51]$. Our data show $P$. beckeri occurring only along the

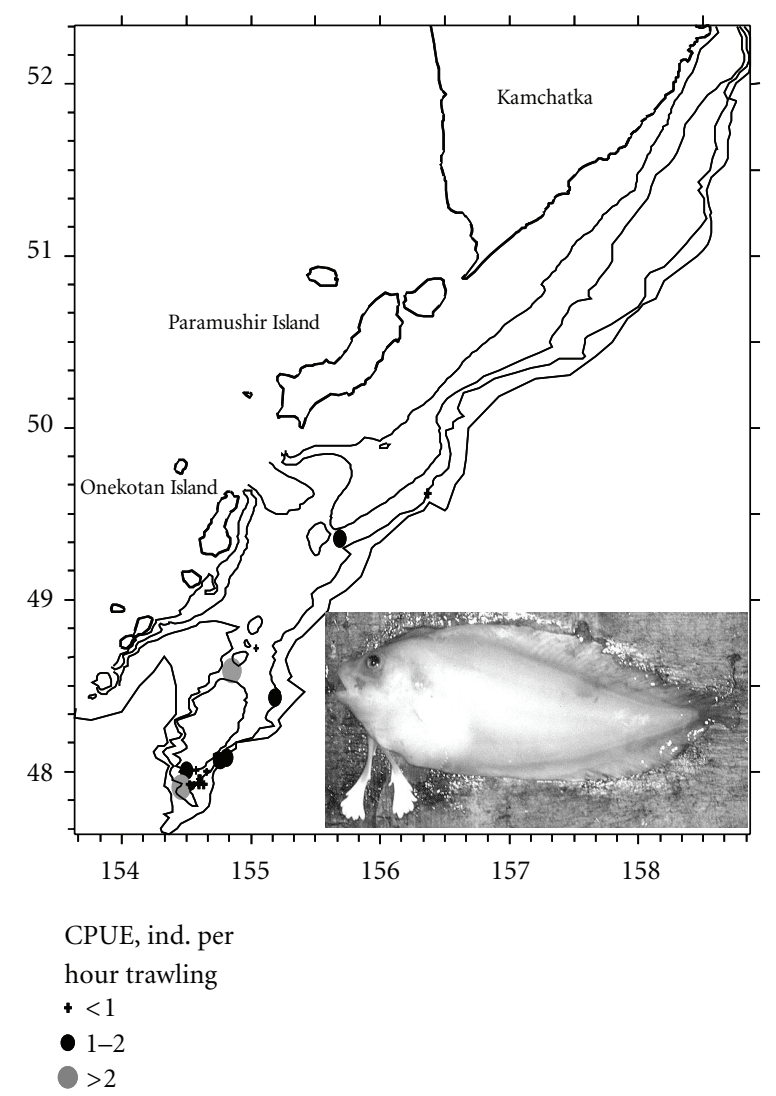

Figure 9: Distribution and relative abundance categorized by CPUE (specimens per hour trawling) of Palmoliparis beckeri in the Pacific waters off northern Kuril Islands, April-December 19952002.

continental slope from $47^{\circ} 50^{\prime} \mathrm{N}$ to the Fourth Kuril Strait, with maximum catches $>2$ specimens/h (Figure 9 ).

$P$. beckeri is a mesobenthic species inhabiting depths of $200-800 \mathrm{~m}$ [7]. Our specimens were collected from that depth range, with near-bottom temperatures of $2.0-3.8^{\circ} \mathrm{C}$. Most specimens (>65\%) were from depths of $300-500 \mathrm{~m}$ (Table 2).

Stout or Cherry Snailfish Allocareproctus jordani. Originally described as Careproctus gilberti based on the holotype and only specimen caught in the Pacific off Honshu [52], Burke [23] later described it as Careproctus jordani. It was subsequently allocated to the genus Allocareproctus [32]. Sheiko and Fedorov [7] consider the species to be a junior synonym of Allocareproctus pycnosoma, [22], although Orr and Busby [21] consider A. jordani as valid. A. jordani is a widely distributed boreal Asiatic species occurring in the Pacific off Japan (Sagami Bay), eastern Sea of Okhotsk, the Kuril Islands and eastern Kamchtka, eastern Bering Sea, and central and eastern Aleutian Islands [5-7, 11, 21, $32,35,36]$. We collected it from $47^{\circ} 50^{\prime}$ to $51^{\circ} 00^{\prime} \mathrm{N}$ (Figure 10), but maximum catches ( $>10$ specimens/h) were obtained from the slopes of underwater plateau and off the Fourth Kuril Strait. To the north, only a few specimens were caught. 
TABLE 3: Weight composition (number of fish within certain weight range) of different snailfish species off the northern Kuril Islands and southeastern Kamchatka.

\begin{tabular}{lccccccccccccccc}
\hline Species & \multicolumn{11}{c}{ Weight, kg } \\
& $<0.1$ & $0.1-0.2$ & $0.2-0.3$ & $0.3-0.4$ & $0.4-0.5$ & $0.5-0.6$ & $0.6-0.7$ & $0.7-0.8$ & $0.8-0.9$ & $0.9-1.0$ & $1.0-1.1$ & $1.1-1.2$ & $>1.2$ & Sample size \\
\hline C. zachirus & 10 & 47 & 28 & 5 & 1 & 0 & 0 & 0 & 0 & 0 & 0 & 0 & 0 & 91 \\
C. colletti & 2 & 2 & 4 & 7 & 1 & 1 & 0 & 0 & 0 & 1 & 0 & 1 & 0 & 19 \\
C. melanurus & 1 & 0 & 0 & 3 & 4 & 6 & 5 & 4 & 4 & 2 & 3 & 1 & 1 & 34 \\
C. cypselurus & 0 & 1 & 19 & 42 & 22 & 10 & 4 & 2 & 0 & 0 & 0 & 0 & 0 & 100 \\
E. obscurus & 9 & 25 & 36 & 24 & 3 & 3 & 0 & 0 & 0 & 0 & 0 & 0 & 0 & 100 \\
P. grandis & 0 & 18 & 24 & 11 & 1 & 1 & 0 & 0 & 0 & 0 & 0 & 0 & 0 & 55 \\
A. jordani & 36 & 20 & 13 & 4 & 1 & 3 & 5 & 3 & 0 & 1 & 0 & 0 & 0 & 86 \\
P. beckeri & 1 & 5 & 3 & 5 & 5 & 2 & 3 & 2 & 0 & 1 & 0 & 0 & 0 & 27 \\
\hline
\end{tabular}

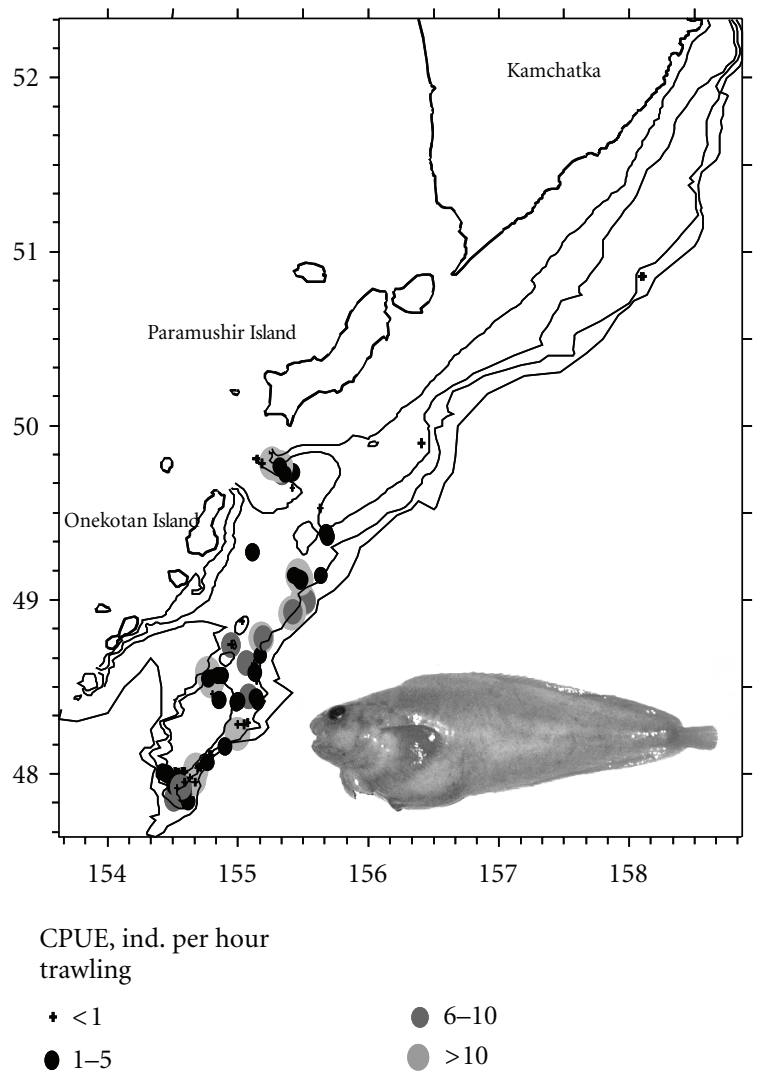

Figure 10: Distribution and relative abundance categorized by CPUE (specimens per hour trawling) of Allocareproctus jordani in the Pacific waters off the northern Kuril Islands and southeastern Kamchatka, April-December 1993-2002.

This species is a mesobenthic species known from depths of 75-700 $\mathrm{m}$ [7]. We caught it between 130-750 $\mathrm{m}$, with nearbottom temperatures of $1.3-3.6^{\circ} \mathrm{C}$ (Table 2), although most specimens $(>87 \%)$ were caught in $300-500 \mathrm{~m}$.

3.2. Length and Weight. Of the five species of Careproctus considered here, C. melanurus and C. colletti reach maximum size in Pacific waters off southeastern Kamchatka and the northern Kuril Islands.

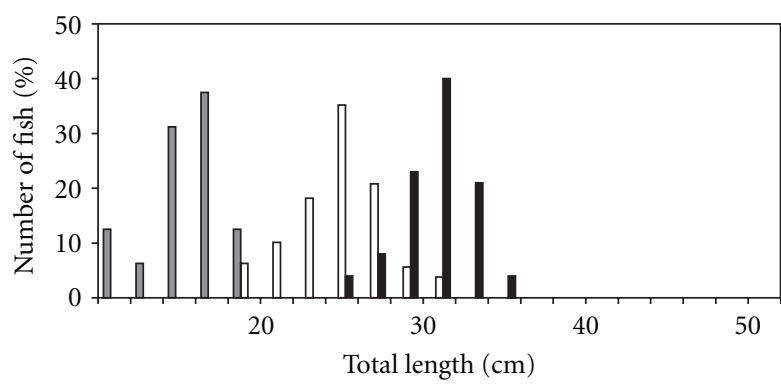

$\square 1$

$\square 2$

(a)

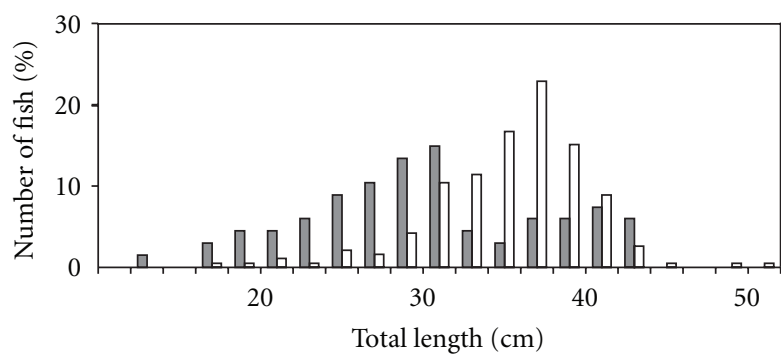

$\square 4$

ㅁ 5

(b)

Figure 11: Size compositions of Careproctus simus (1), C. zachirus (2), C. cypselurus (3), C. colletti (4), and C. melanurus (5) in the Pacific waters off the northern Kuril Islands and southeastern Kamchatka, 1993-2002.

Careproctus melanurus were $18-51 \mathrm{~cm}(35.4 \mathrm{~cm}$ average) in length and $100-1,700 \mathrm{~g}$ ( $728 \mathrm{~g}$ average $)$ in weight; C. colletti were $14-44 \mathrm{~cm}(30.1 \mathrm{~cm}$ average) and 70-1,200 g (381 g average; Figure 11, Table 3 ), although specimens of $C$. melanurus of 30-40 cm (77\%) and 450-900 g (68\%) and C. colletti 23$32 \mathrm{~cm}(54 \%)$ and $200-400 \mathrm{~g}(58 \%)$ were more abundant. Maximum length of C. melanurus in American waters is estimated to be $26 \mathrm{~cm} \mathrm{[53],} \mathrm{although} \mathrm{on} \mathrm{the} \mathrm{Oregon} \mathrm{slope}$ specimens of up to $31.2 \mathrm{~cm}$ have been caught [54]. Our data 


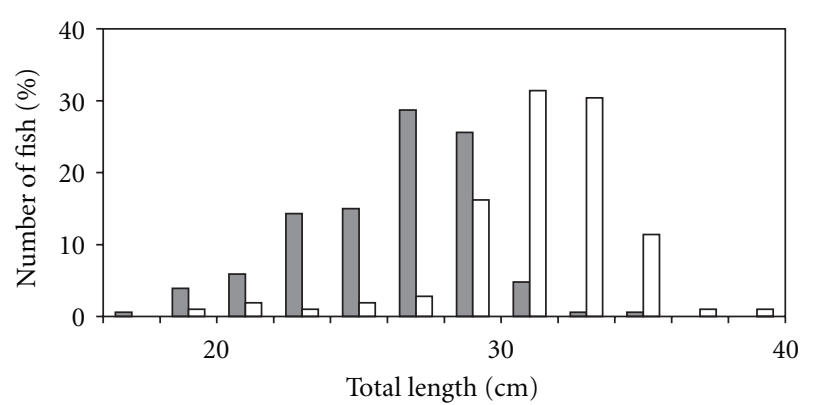

$\square 1$

$$
\square 2
$$

Figure 12: Size compositions of Elassodiscus obscurus (1) and Paraliparis grandis (2) in the Pacific waters off the northern Kuril Islands and southeastern Kamchatka, 1993-2002.

suggested that C. melanurus is significantly larger off the Asian coast; in the western Bering Sea it reaches $54 \mathrm{~cm}$ length [43].

Both C. zachirus and C. cypselurus are smaller than C. melanurus and C. colletti, with maximum lengths of only 32 and $36 \mathrm{~cm}$, respectively $[35,55]$. In our data, C. zachirus ranged from 19 to $32 \mathrm{~cm}(24.7 \mathrm{~cm}$ average $)$ and 80 to $500 \mathrm{~g}$ (194 g average); C. cypselurus ranged from 26 to $36 \mathrm{~cm}$ ( $30.6 \mathrm{~cm}$ average) and 100 to $800 \mathrm{~g}$ (291 g average). Smaller C. zachirus of $24-28 \mathrm{~cm}(56 \%)$ and $100-300 \mathrm{~g}(>82 \%)$ and C. cypselurus of $28-34 \mathrm{~cm}(84 \%)$ and $100-400 \mathrm{~g}(83 \%)$ were more common (Figure 11, Table 3).

The maximum known length of C. simus is $18.6 \mathrm{~cm}$ [46]. Off the northern Kuril Islands, individuals of $12-$ $19 \mathrm{~cm}$ (15.6 cm average) (Figure 11) weighing 30-100 g (75 g average) occurred in trawl catches, but fish of $15-18 \mathrm{~cm}$ in length $(69 \%)$ dominated.

Tokranov [55] recorded the maximum sizes of Elassodiscus obscurus and Paraliparis grandis in the Pacific off the southeastern Kamchatka and northern Kuril Islands at 35$40 \mathrm{~cm}$ and $0.6 \mathrm{~kg}$. Our E. obscurus were represented by fish of $17-35 \mathrm{~cm}$ (26.2 cm average) and 100-600 g (250 g average); P. grandis were $19-40 \mathrm{~cm}(31.3 \mathrm{~cm}$ average $)$ and $120-600 \mathrm{~g}$ (250 g average). However, E. obscurus of $22-30 \mathrm{~cm}(84 \%)$ and $100-400 \mathrm{~g}(85 \%)$ and P. grandis $28-36 \mathrm{~cm}(>89 \%)$ and 100 $400 \mathrm{~g}$ (about 96\%; Figure 12, Table 3) formed most of the catches.

In the literature, $S$. dentatus reaches $34.6 \mathrm{~cm} \mathrm{[31]} \mathrm{and}$ $P$. beckeri and A. jordani $38 \mathrm{~cm}$ and $1 \mathrm{~kg}[34,35]$. We collected $S$. dentatus of $20-39 \mathrm{~cm}(29.6 \mathrm{~cm}$ average $)$ and $100-1,300 \mathrm{~g}$ (680 g average); P. beckeri of $15-38 \mathrm{~cm}(28.9 \mathrm{~cm}$ average) and $60-1,000 \mathrm{~g}$ (414 g average), and $A$. jordani of $10-38 \mathrm{~cm}(21.6 \mathrm{~cm}$ average $)$ and $50-1,000 \mathrm{~g}$ (210 g average; Figure 13, Table 3). However, S. dentatus of $26-34 \mathrm{~cm}$ (54\%) weighing $500-900 \mathrm{~g}$ (over 65\%), P. beckeri of $26-36 \mathrm{~cm}$ (78\%) and 100-500 g (about 67\%), and A. jordani of 16$24 \mathrm{~cm}(54 \%)$ weighing less than $200 \mathrm{~g}(65 \%)$ occurred most frequently.

Length-weight relationships were obtained for all snailfish species considered here (Table 4). The values of param-

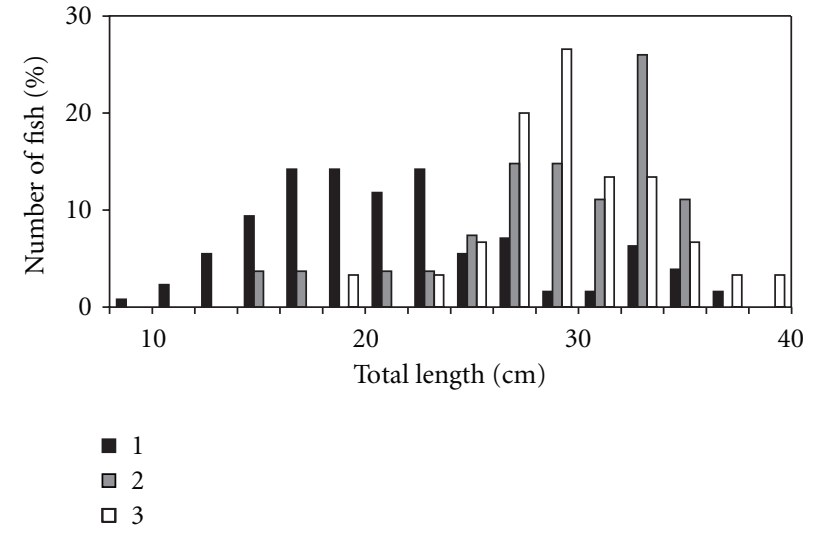

FIgure 13: Size compositions of Allocareproctus jordani (1), Squaloliparis dentatus (2), and Palmoliparis beckeri (3) in the Pacific waters off the northern Kuril Islands and southeastern Kamchatka, 19952002.

TABle 4: Parameters and coefficient of determination $\left(R^{2}\right)$ of equation of total length- (TL-) weight (W) relationship $\mathrm{W}=a \mathrm{TL}^{b}$ in different snailfish species off the northern Kuril Islands and southeastern Kamchatka.

\begin{tabular}{lccc}
\hline Species & $a$ & $b$ & $R^{2}$ \\
\hline Allocareproctus jordani & $9.2 \times 10^{-3}$ & 3.1722 & 0.810 \\
Careproctus zachirus & $7.4 \times 10^{-2}$ & 2.4269 & 0.458 \\
C. colletti & $1.9 \times 10^{-3}$ & 3.5819 & 0.886 \\
C. cypselurus & $8.5 \times 10^{-3}$ & 3.1222 & 0.641 \\
C. melanurus & $7.0 \times 10^{-3}$ & 3.1953 & 0.828 \\
C. simus & 3.174 & 1.8968 & 0.692 \\
Elassodiscus obscurus & $6.8 \times 10^{-3}$ & 3.2048 & 0.817 \\
Palmoliparis beckeri & 1.015 & 2.4522 & 0.811 \\
Paraliparis grandis & 0.176 & 2.1032 & 0.522 \\
Squaloliparis dentatus & $5.1 \times 10^{-3}$ & 3.4012 & 0.873 \\
\hline
\end{tabular}

eter $b$ for the majority of the species examined (with the exception of $C$. simus and $P$. grandis) were generally within the normal range (2.5-3.5) for fish [56], indicating isometric growth during their life span [57]. Species with similar values of parameters $a$ and $b$ are C. cypselurus, C. melanurus, E. obscurus, and S. dentatus, indicating similar growth in these species.

3.3. Age and Age Composition. Based on our age determinations from otoliths and on the sizes of the specimens we collected, we conclude that the maximum age of the species considered here and of species of this family is less than $10-13$ years $[35,55]$, and that specimens of $2-5$ age classes (Table 5) constitute the main part (73-97\%) of the catch of each species (Figure 14).

3.4. Diet. We found that all the species we studied are benthophages feeding mainly on bottom and near-bottom organisms, primarily crustaceans $[20,35,58]$. The four 


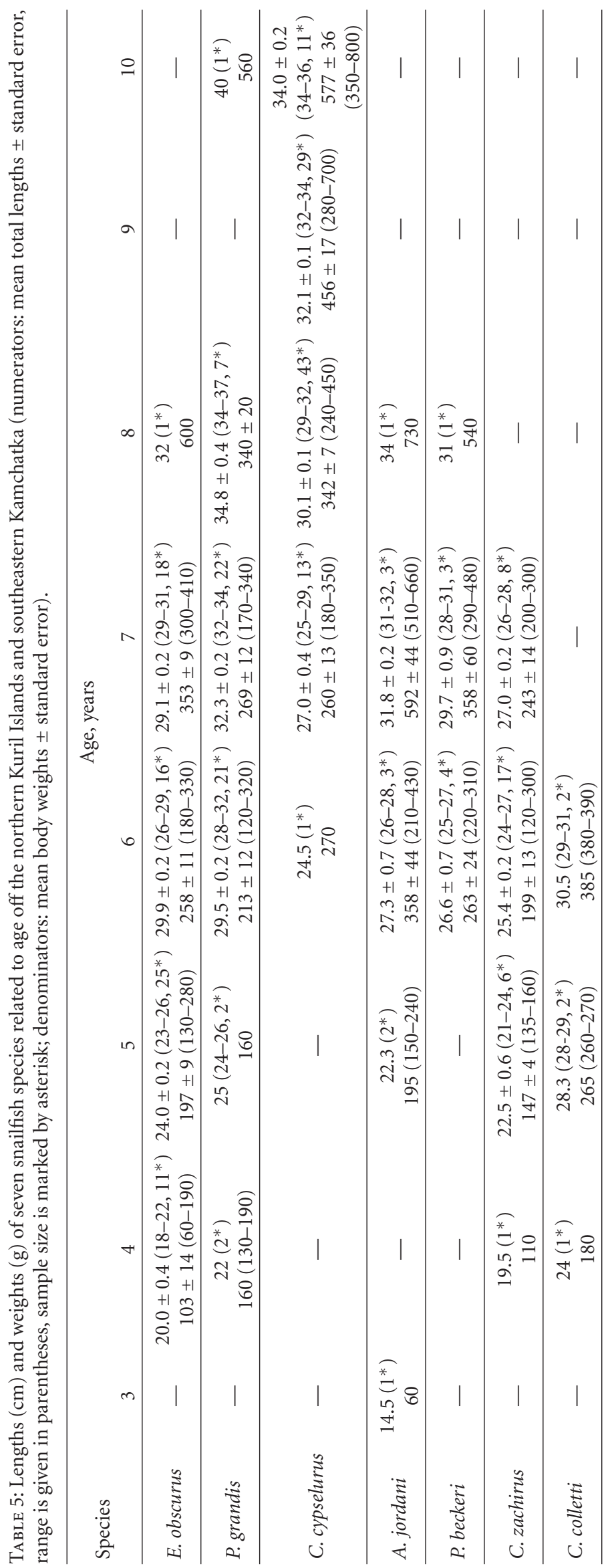


TABLE 6: Frequency of occurrence of food items in stomachs of eight snailfish species off the northern Kuril Islands and southeastern Kamchatka.

\begin{tabular}{|c|c|c|c|c|c|c|c|c|}
\hline \multirow{2}{*}{ Dietary component } & \multicolumn{8}{|c|}{ Species } \\
\hline & C. zachirus & C. colletti & C. melanurus & C. cypselurus & E. obscurus & P. grandis & P. beckeri & A. jordani \\
\hline Anthozoa & - & 20.0 & - & - & - & - & - & - \\
\hline Polychaeta & 3.1 & - & - & - & - & 3.6 & - & 20.0 \\
\hline Ostracoda & - & - & - & - & - & - & 10.0 & - \\
\hline Cumacea & - & - & - & - & 3.0 & - & - & - \\
\hline Amphipoda & 25.0 & - & 20.0 & 25.0 & 65.0 & 56.4 & 10.0 & 10.0 \\
\hline Euphausiacea & - & - & - & 1.0 & - & - & - & - \\
\hline Decapoda & 65.6 & 40.0 & 80.0 & 37.0 & 61.0 & - & 90.0 & 30.0 \\
\hline Bivalvia & 3.1 & - & 一 & - & - & - & - & - \\
\hline Gastropoda & - & - & - & - & - & - & - & 10.0 \\
\hline Octopoda & - & - & - & - & - & - & - & 10.0 \\
\hline Ophiuroidea & - & - & - & - & - & - & - & 10.0 \\
\hline Pisces & - & - & - & 5.0 & 3.0 & - & 10.0 & 20.0 \\
\hline Fish eggs & 3.1 & - & - & - & - & - & - & - \\
\hline Fishery offal & - & - & - & - & - & - & - & 10.0 \\
\hline Unidentified organic material & 一 & 20.0 & 一 & - & - & - & 一 & - \\
\hline Number of fish examined & 32 & 5 & 5 & 100 & 100 & 55 & 10 & 10 \\
\hline Percent of empty stomachs & 21.9 & 20.0 & 20.0 & 41.2 & 48.4 & 48.0 & - & 20.0 \\
\hline
\end{tabular}

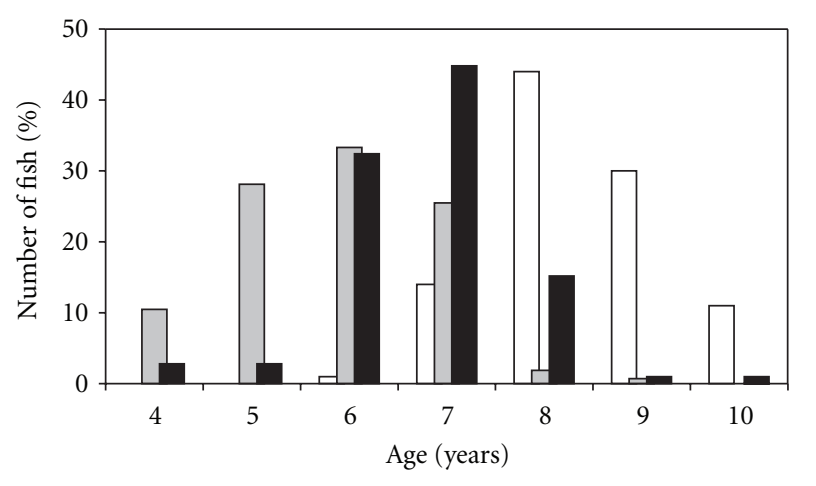

$\square 1$

$\square 2$

- 3

Figure 14: Age compositions of Careproctus cypselurus (1), Elassodiscus obscurus (2), and Paraliparis grandis (3) in the Pacific off northern Kuril Islands and southeastern Kamchatka, 1993-2002.

species of genus Careproctus (C. zachirus, C. colletti, C. melanurus, C. cypselurus) and also E. obscurus, P. grandis, and $P$. becker eat a rather limited food spectrum consisting of 2-5 groups of invertebrates and fish (Table 6). However, small shrimps (mainly of family Hippolytidae), hermit crabs Pagurus spp., and amphipods (total occurrence greater than $80-90 \%)$ are their main diet. A. jordani has a significantly broader diet of crustaceans (40\%), polychaete worms, sea snails (Gastropoda), octopi (Octopoda), brittle stars (Ophiuroidea), as well as juvenile fish and fishery offal.

\section{Conclusion}

The results of research conducted in 1993-2000 allowed us to conclude that proboscis snailfish, big-disc snailfish, and gloved snailfish occur only in a limited part of the Pacific continental slope off the northern Kuril Islands south of the Fourth Kuril Strait; the maximum catches of all these three species have been recorded exclusively in the area of the underwater elevation in the northern link of the outer ridge of the Kuril chain. The range of stout snailfish and blacktip snailfish is somewhat wider: the former was found up to $51^{\circ}$ $00^{\prime} \mathrm{N}$; the latter at up to $51^{\circ} 30^{\prime} \mathrm{N}$, though their greatest catches tended to be taken near the underwater elevation and Fourth Kuril Strait too. Unlike them, the falcate snailfish, blacktail snailfish, longtip snailfish, slender snailfish, and Alaska snailfish were observed throughout the entire area surveyed during the period of study. However, while the largest catches of the former species occurred mostly in the southern part of that area, the biggest catches of the blacktail, longtip, and slender snailfish were, in contrast to that, recorded in the northern and central parts. The Alaska snailfish used to be caught in about equal numbers both in the north and in the south of the area examined on the Pacific side of the northern Kuril Islands and southeastern Kamchatka.

All the snailfish surveyed inhabit a broad bathymetric range between April and December, though the deepest species of them are the blacktail, falcate, longtip, slender, and Alaska snailfish whose upper range limit does not rise over 260-300 m; those fish stay mostly at bottom temperatures over $3^{\circ} \mathrm{C}$. The proboscis snailfish and big-disc snailfish are 
found mostly within 300-600 m. Unlike these fish, the other three species, especially stout and blacktip snailfish, occur sporadically at 150-200; the gloved and stout snailfish can fairly often be found at much lower bottom temperatures.

The life span of all the snailfish examined, as in most of the other representatives of this family, does not exceed 1013 years while the catches of each of them taken in the Pacific off the northern Kuril Islands and southeastern Kamchatka basically (73-97\%) comprise individuals aged 2-5 years.

The body length-weight relationship analysis of the snailfish studied shows that despite the differences in body shape most of them have isometric pattern of growth.

All the snailfish examined except stout snailfish are benthophagous with rather narrow food ranges. Their major dietary components are various small bottom or nearbottom crustaceans (shrimp, hermit crabs Pagurus spp., and amphipods). Unlike them, the diet of stout snailfish is much wider; in addition to crustaceans, it includes polychaet worms, sea snails Gastropoda, bivalves Bivalvia, brittle stars Ophiuroidea, as well as young fish and fishey offal.

\section{Acknowledgments}

Authors would like to express their gratitude to all the scientists of VNIRO, KamchatNIRO, SakhNIRO and other institutions who, between 1993 and 2002, collected data used in this paper. We also thank the assistance of Tomio Iwamoto (Department of Ichthyology, California Academy of Sciences, San Francisco, USA) who helped improve the English.

\section{References}

[1] S. W. Knudsen, P. R. Møller, and P. Gravlund, "Phylogeny of the snailfishes (Teleostei: Liparidae) based on molecular and morphological data," Molecular Phylogenetics and Evolution, vol. 44, no. 2, pp. 649-666, 2007.

[2] G. U. Lindberg, "Family liparids, or snailfishes (Liparidae)," in Wildlife, T. S. Rass, Ed., vol. 1, part 4, pp. 579-581, Prosveshcheniye, Moscow, Russia, 1971.

[3] L. A. Borets, Bottom Ichthyocenes of the Russian Far East Seas Shelf: Composition, Structure, Functioning Elements and Commercial Importance, TINRO-Center, Vladivostok, Russia, 1997.

[4] L. A. Borets, Annotated List of Fishes of the Far East Seas, TINRO-Center, Vladivostok, Russia, 2000.

[5] A. M. Orlov, "Demersal ichthyofauna of Pacific waters around the Kuril Islands and southeastern Kamchatka," Biologiya Morya, vol. 24, no. 3, pp. 144-160, 1998 (Russian).

[6] V. V. Fedorov, "Species composition, distribution and habitation depths of the Northern Kuril Islands fish and fish-like species," in Commercial and Biological Studies of Fishes in the Pacific Waters of the Kuril Islands and Adjacent Areas of the Okhotsk and Bering Seas in 1992-1998, B. N. Kotenev, Ed., pp. 7-41, VNIRO, Moscow, Russia, 2000.

[7] B. A. Sheiko and V. V. Fedorov, "Class cephalaspidomorphilampreys. Class chondrichthyes - cartilaginous fishes. Class holocephali-chimaeras. Class osteichthyes-bony fishes," in Catalogue of Vertebrates of Kamchatka and Adjacent Waters, R. S. Moiseev and A. M. Tokranov, Eds., chapter 1, pp. 769, Kamchatskii Pechatnyi Dvor, Petropavlovsk-Kamchatsky, Russia, 2000.
[8] E. N. Il'insky, "Long-term changes of catch composition of dominant bottom fish on the continental slope of the Far East seas," Izvestiya TINRO, vol. 111, pp. 67-78, 1990 (Russian).

[9] Y. I. Dudnik and V. N. Dolganov, "Distribution and fish stocks on the continental slope of the Okhotsk Sea and Kuril Islands," Voprosy Ikhtiologii, vol. 32, no. 4, pp. 83-98, 1992 (Russian).

[10] A. M. Orlov, A. M. Tokranov, and S. N. Tarasyuk, "Composition and dynamics of the bottom fish communities on the Pacific upper continental slope off the northern Kuril Islands and southeast Kamchatka," Voprosy Rybolovstva, vol. 1, no. 4, pp. 21-45, 2000 (Russian).

[11] A. M. Tokranov, "Species composition and spatial distribution of snailfishes (Liparidae) in the Pacific waters of southeastern Kamchatka and northern Kuril Islands," Voprosy Ikhtiologii, vol. 40, no. 2, pp. 176-186, 2000 (Russian).

[12] V. K. Soldatov and G. U. Lindberg, "A review of the fishes of the seas of the Far East," Izvestiya TINRO, vol. 5, pp. 1-576, 1930 (Russian).

[13] A. Y. Taranets, "Handbook for identification of fishes of Soviet Far East and adjacent waters," Izvestiya TINRO, vol. 11, pp. 1200, 1937 (Russian).

[14] A. P. Andriashev, An Outline of the Zoogeography and Origin of the Fish Fauna of the Bering Sea and Neighboring Waters, Izdatel'stvo Leningradskogo Gosudarstvennogo Universiteta, Leningrad, Russia, 1939.

[15] A. P. Andriashev, Fishes of the Northern Seas of the U.S.S.R., Izdatel'stvo Akademii Nauk SSSR, Moscow, Russia, 1954.

[16] T. Ueno, "List of the Marine fishes from the waters of Hokkaido and its adjacent regions," Scientific Reports of the Hokkaido Fisheries Experimental Station, vol. 13, pp. 61-102, 1971.

[17] R. H. Parrish, "Symbiosis in the blacktail snailfish, Careproctus melanurus, and the box crab, Lopholithodes foraminatus," California Department of Fish and Game, vol. 58, no. 3, pp. 239-240, 1972.

[18] J. C. Quast and E. L. Hall, List of Fishes of Alaska and Adjacent Waters with a Guide to some of Their Literature, NOAA Tech. Rep. NMFS SSRF-658, United States Department of Commerce, 1972.

[19] M. J. Allen and G. B. Smith, Atlas and Zoogeography of Common Fishes in the Bering Sea and Northeastern Pacific, NOAA Technical Report NMFS, 66, US Department of Commerce, 1988.

[20] A. M. Tokranov, "Feeding of snailfishes (Liparidae) in the Pacific waters of southeastern Kamchatka and northern Kuril Islands," Voprosy Ikhtiologii, vol. 40, no. 4, pp. 530-536, 2000 (Russian).

[21] J. W. Orr and M. S. Busby, "Revision of the snailfish genus Allocareproctus Pitruk et Fedorov (Teleostei: Liparidae), with descriptions of four new species from the Aleutian Islands," Zootaxa, no. 1173, pp. 1-37, 2006.

[22] C. H. Gilbert and C. V. Burke, "Fishes from Bering Sea and Kamchatka," The Bulletin of the United States Bureau of Fisheries, vol. 30, pp. 31-96, 1912.

[23] V. Burke, "Revision of the fishes of the family Liparidae," Bulletin of the United States National Museum, vol. 150, pp. 1-204, 1930.

[24] J. L. Hart, "Pacific fishes of Canada," Bulletin of the Fisheries Research Board of Canada, vol. 180, pp. 1-740, 1973.

[25] D. L. Stein, "A review of the deepwater Liparidae (Pisces) from the coast of Oregon and adjacent waters," Occasional Papers of the California Academy of Sciences, vol. 127, pp. 1-55, 1978. 
[26] K. Kido, "New and rare liparidid species from the Okhotsk and Bering Seas and their adjacent waters," Japanese Journal of Ichthyology, vol. 29, no. 4, pp. 374-384, 1983.

[27] K. Kido, "New and rare species of the genus Careproctus (Liparididae) from the Bering Sea," Japanese Journal of Ichthyology, vol. 32, no. 1, pp. 6-17, 1985.

[28] K. Kido, "Phylogeny of the family Liparididae, with taxonomy of the species found around Japan," Memoirs of the Faculty of Fisheries, Hokkaido University, vol. 35, no. 2, pp. 125-256, 1988.

[29] H. Masuda, K. Amaoka, C. Araga, T. Uyeno, and T. Yoshino, The Fishes of the Japanese Archipelago, Tokai University Press, Tokyo, Japan, 1984.

[30] D. L. Pitruk and V. V. Fedorov, "On validation of the genus Elassodiscus Gilbert et Burke, 1912 (Scorpaeniformes, Liparidae) with description of new species from the Sea of Okhotsk," Voprosy Ikhtiologii, vol. 33, no. 6, pp. 165-175, 1993 (Russian).

[31] D. L. Pitruk and V. V. Fedorov, "Squaloliparis gen. novum (Scorpaeniformes, Liparidae)—new genus liparid fishes from the bathyal of the Sea of Okhotsk," Voprosy Ikhtiologii, vol. 33, no. 5, pp. 602-608, 1993 (Russian).

[32] D. L. Pitruk and V. V. Fedorov, "Allocareproctus gen. novum (Scorpaeniformes, Liparidae)—new genus of liparid fishes from the northwestern Pacific Ocean," Voprosy Ikhtiologii, vol. 33, no. 1, pp. 16-20, 1993 (Russian).

[33] K. Amaoka, K. Nakaya, and M. Yabe, The Fishes of Northern Japan, Kita-Nihon Kaijo Center, Sapporo, Japan, 1995.

[34] A. V. Balushkin, "New genus and species of snailfish Palmoliparis beckeri (Scorpaeniformes, Liparidae) from the northern Kuril Islands with notes on phylogeny of the family," Voprosy Ikhtiologii, vol. 36, no. 3, pp. 293-299, 1996 (Russian).

[35] A. M. Tokranov and A. M. Orlov, "Some biological features of rare snailfish species (Liparidae) in the Pacific waters off the northern Kuril Islands and southeastern Kamchatka," in Conservation of Biodiversity of Kamchatka and Adjacent Seas, C. G. Korostelev, R. S. Moiseev, A. M. Tokranov, and O. A. Chernyagina, Eds., 2nd Materials Science Conference, pp. 187-190, Kamshat, Petropavlovsk-Kamchatsky, Russia, 2001.

[36] N. V. Chernova, D. L. Stein, and A. P. Andriashev, "Family Liparidae Scopoli 1777-snailfishes," California Academy of Sciences Annotated Checklists of Fishes, vol. 31, pp. 1-72, 2004.

[37] C. W. Mecklenburg, T. A. Mecklenburg, and L. K. Thorsteinson, Fishes of Alaska, American Fisheries Society, Bethesda, Md, USA, 2002.

[38] W. E. Barraclough and M. Waldichuk, "Offshore characteristics in the deep waters of the Strait of Georgia as indicated by bathypelagic fish," Journal of the Fisheries Research Board of Canada, vol. 5, pp. 501-506, 1954.

[39] W. A. Clemens and G. V. Wilby, "Fishes of the Pacific Coast of Canada," Bulletin of the Fisheries Research Board of Canada, vol. 68, pp. 1-343, 1961.

[40] C. R. Forrester and R. M. Wilson, "A further record of the blacktail snailfish, Careproctus melanurus Gilbert, from British Columbia," Journal of the Fisheries Research Board of Canada, vol. 20, pp. 1095-1097, 1963.

[41] J. E. Fitch and R. J. Lavenberg, Deep-Water Fishes of California, University of California Press, Berkeley, Calif, USA, 1968.

[42] V. V. Fedorov, “A list of Bering Sea fish," Izvestiya TINRO, vol. 87, pp. 42-71, 1973 (Russian).

[43] A. M. Orlov, "Representatives of Oregonian ichthyofauna off the Asian coasts," in Commercial and Biological Studies of Fishes in the Pacific Waters of the Kuril Islands and Adjacent Areas of the Okhotsk and Bering Seas in 1992-1998, B. N. Kotenev, Ed., pp. 187-214, VNIRO, Moscow, Russia, 2000.
[44] K. Kido and G. Shinohara, "First Record of a liparid fish, Careproctus melanurus (Teleostei, Scorpaeniformes), from Japan," Bulletin of the National Science Museum, Tokyo A, vol. 23, pp. 127-130, 1997.

[45] G. M. Cailliet, A. H. Andrews, W. W. Wakefield, G. Moreno, and K. L. Rhodes, "Fish faunal and habitat analyses using trawls, camera sleds and submersibles in benthic deep-sea habitats off central California," Oceanologica Acta, vol. 22, no. 6, pp. 579-592, 1999.

[46] D. Tsutsui and K. Amaoka, "First record of the snail fish, Careproctus simus (Scorpaeniformes: Liparidae), from Japan," Ichthyological Research, vol. 44, no. 1, pp. 89-91, 1997.

[47] D. A. Somerton and W. Donaldson, "Parasitism of the golden king crab, Lithodes aequispinus, by two species of snailfish, genus Careproctus," Fishery Bulletin, vol. 96, no. 4, pp. 871884, 1998.

[48] P. Y. Schmidt, "Fishes of the Sea of Okhotsk," Trans-Pacific Communications, vol. 6, pp. 1-370, 1950 (Russian).

[49] D. L. Pitruk, "Preliminary checklist of species and distribution of fishes of family Liparididae in the Sea of Okhotsk," Trudy ZIN AN SSSR, vol. 213, pp. 35-45, 1990 (Russian).

[50] N. V. Chernova, "Catalogue of type specimens of fishes of the family Liparidae (Scorpaeniformes) in collections of the Zoological Institute RAS," Voprosy Ikhtiologii, vol. 38, no. 6, pp. 760-775, 1998 (Russian).

[51] A. V. Balushkin and V. P. Prirodina, "Second record of Palmoliparis beckeri (Liparidae) off the northern Kuril Islands," Voprosy Ikhtiologii, vol. 40, no. 1, pp. 97-99, 2000 (Russian).

[52] D. S. Jordan and W. F. Thompson, "Record of the fishes obtained in Japan in 1911," Memoirs of the Carnegie Museum, vol. 4, pp. 205-313, 1914.

[53] W. N. Eschmeyer, E. S. Herald, and H. Hamman, A Field Guide to Pacific Coast Fishes, Houghton Mifflin, Boston, Mass, USA, 1983.

[54] D. L. Stein, "Aspects of reproduction of liparid fishes from the continental slope and abyssal plain off Oregon, with notes on growth," Copeia, vol. 4, pp. 687-699, 1980.

[55] A. M. Tokranov, "Size-age composition of snailfishes (Liparidae) in the Pacific waters of southeastern Kamchatka and northern Kuril Islands," Voprosy Ikhtiologii, vol. 40, no. 3, pp. 347-352, 2000 (Russian).

[56] K. D. Carlander, Handbook of Freshwater Fishery Biology, vol. 1, The Iowa State University Press, Ames, Iowa, USA, 1969.

[57] R. S. Zotina and A. I. Zotin, "Quantitative relationships between weight, length, age, egg size, and fecundity in animals," Zhurnal Obshchei Biologii, vol. 28, no. 1, pp. 82-92, 1967 (Russian).

[58] A. M. Orlov, "Diet composition and trophic relations of some non-commercial fishes of the western Bering Sea continental slope," in Problems of Conservation and Rational Use of Kamchatka Bioresources, A. M. Tokranov and N. A. Chebanov, Eds., Conference Registration Abstract on Science and Practice, pp. 77-78, Goskomkamchatecologiya, PetropavlovskKamchatsky, Russia, 1999. 

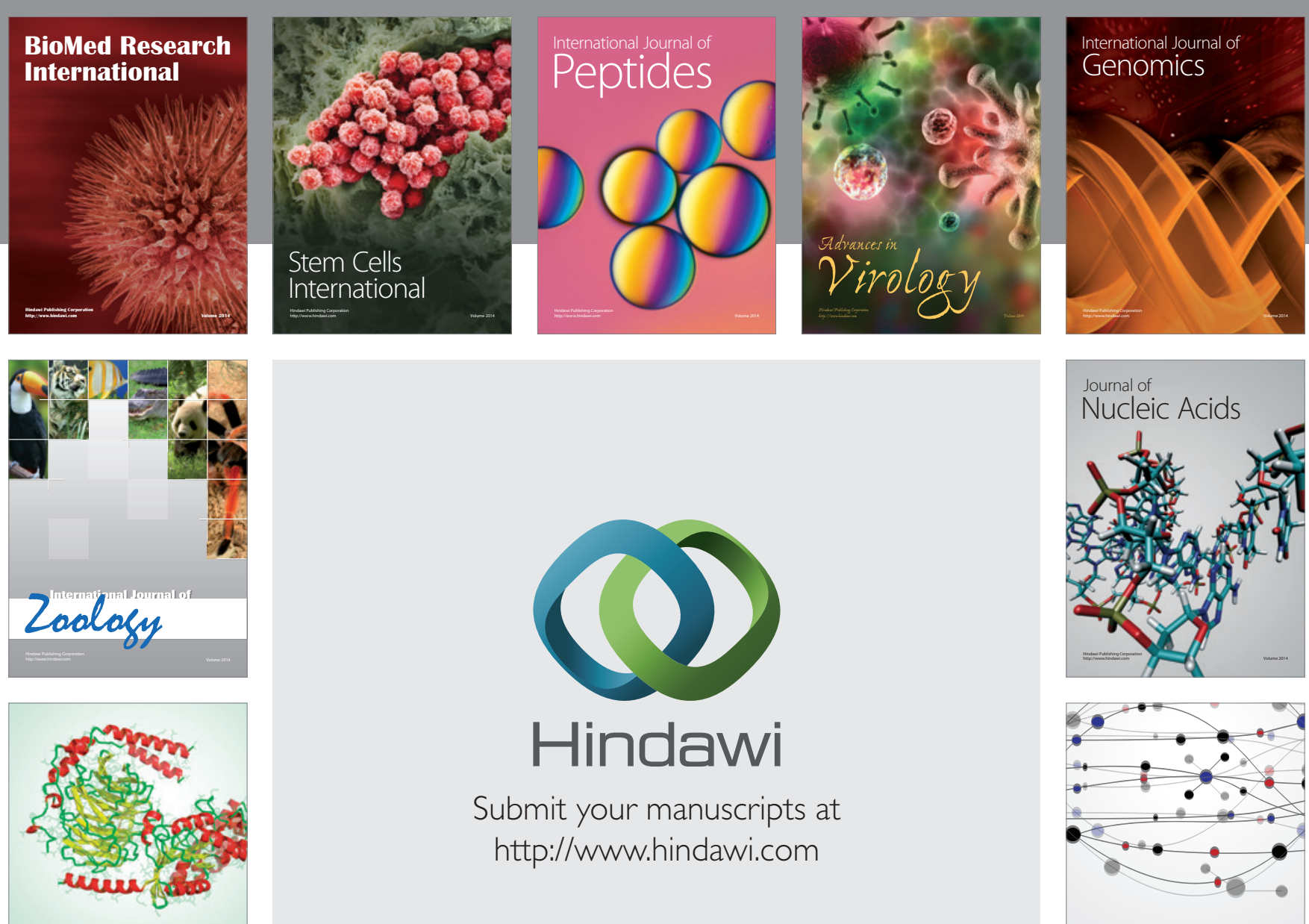

Submit your manuscripts at

http://www.hindawi.com

Signal ${ }^{\text {Jumal }}$ Transduction
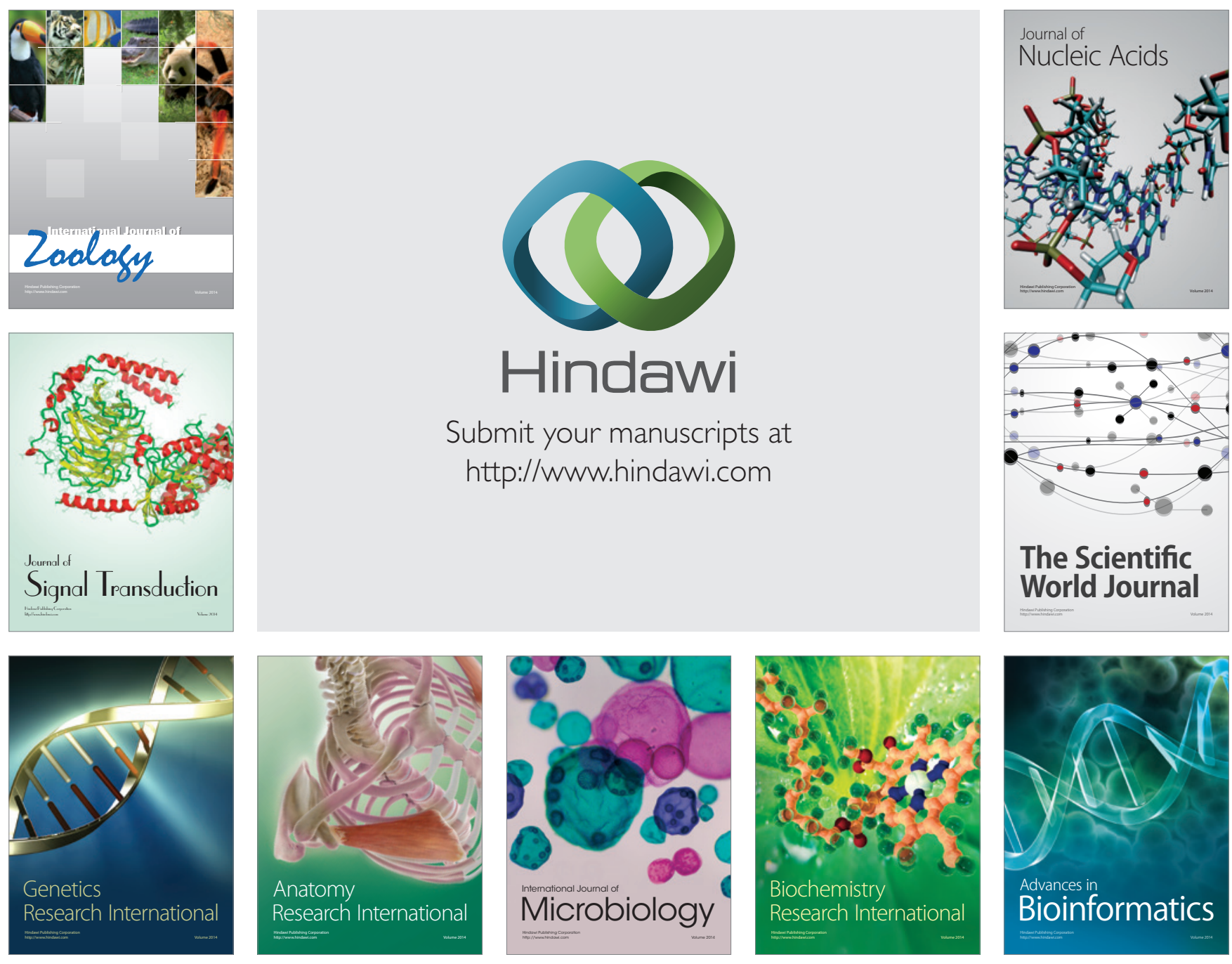

The Scientific World Journal
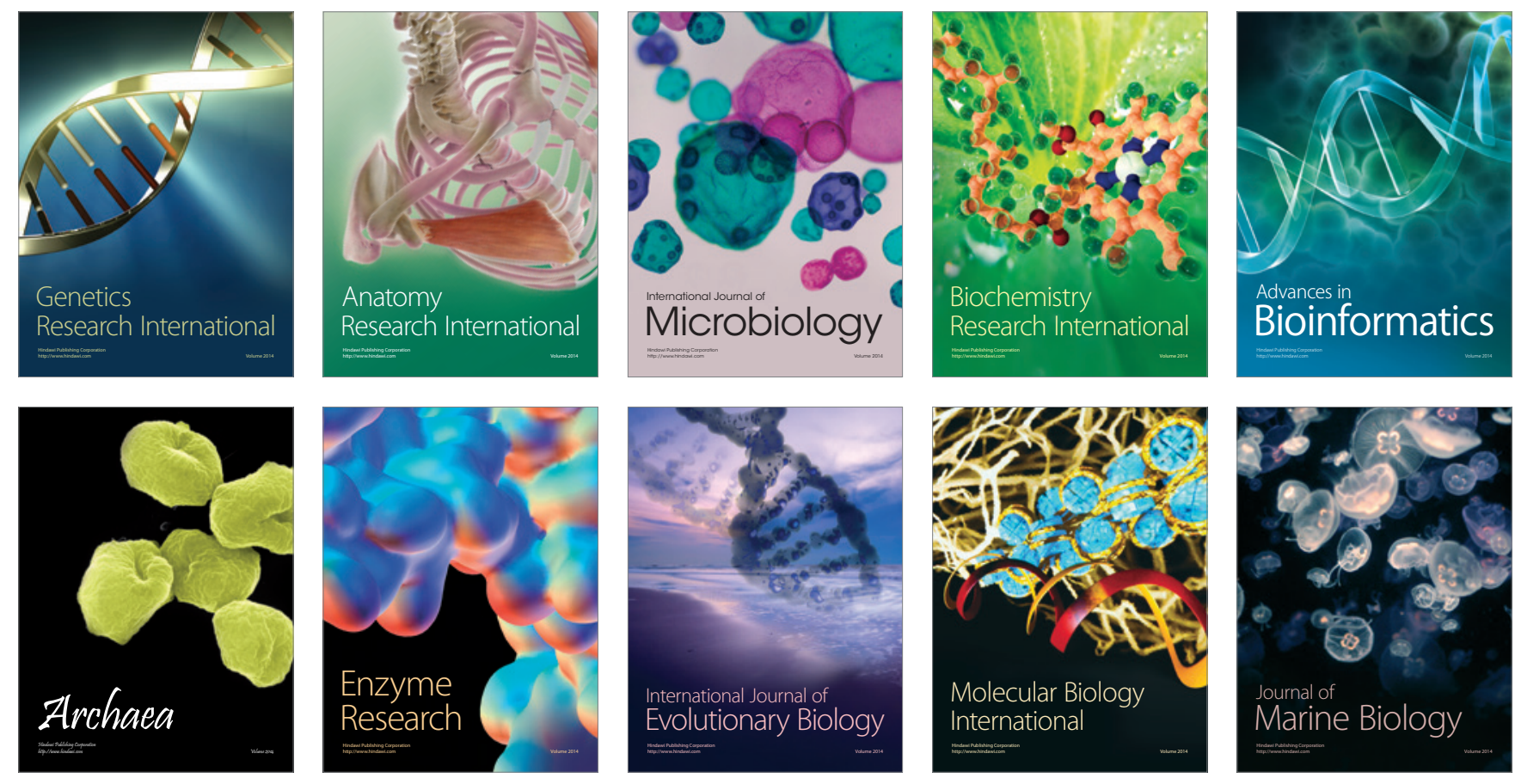